УДК [329.73СВУ:323.2(477)] «1914/1918»

\title{
ПАТЕР І.Г.
}

https:// orcid.org/0000-0003-4340-7735

https://doi.org/10.33577/2313-5603.35.2021.81-113

\section{СОЮЗ ВИЗВОЛЕННЯ УКРАЇНИ: ВІЙСЬКОВО-ПОЛІТИЧНИЙ АСПЕКТ (1914-1918 рр.)}

Початок Першої світової війни призвів до заснування наддніпрянськими політичними емігрантами Союзу визволення України (СВУ), основним постулатом якого стало розбиття царської Росії та угворення незалежної Української держави. Бойові дії на російсько-австро-угорсько-німецькому фронті спричинилися до появи великої кількості вояків-українців у таборах військовополонених російської армії на території Австро-Угорщини та Німеччини.

Наголошено на заходах СВУ перед урядовими чинниками Центральних держав, завдяки чому вдалося виокремити сотні тисяч полонених українців в окремі табори, ізолювавши їх від російського впливу, і поширювати серед них ідею визволення українського народу. Акцентовано на діях керівництва СВУ щодо переконання впливових німецьких та австро-угорських кіл у необхідності здійснення комплексу політичних заходів, спрямованих на зміцнення національної самосвідомості вояків-українців. Зазначено розгортання широкої національнопатріотичної та культурно-просвітньої роботи Союзу серед полонених українців, окремо солдатського складу та офіцерів. Висвітлено результати наполегливої праці СВУ: зорганізування Українських громад у таборах, залучення значної кількості полонених до українства, а 3 угворенням Центральної Ради і проголошенням самостійності України моральна і психологічна їх підготовка до захисту своєї Вітчизни, успішне проведення у середовищі таборян формування дивізій Сірота Синьожупанників, вояки яких стали одним із важливих елементів творення української національної армії в добу визвольних змагань 1917-1920 pp.

Ключові слова: Союз визволення України, табори полонених, національноосвідомлююча праця, військо.

Постановка проблеми та ї̈ актуальність. Військова історія України, зокрема періоду Першої світової війни, незважаючи на значну кількість публікацій ще недостатньо висвітлена українською історичною наукою. Це стосується й військово-політичної діяльності СВУ серед полонених українців російської армії у таборах Австро-Угорщини та Німеччини, передусім щодо піднесення їх національної свідомості, розкриття тих труднощів, що довелося переборювати діячам Союзу, особливо на початковому

Патер Іван Григорович, доктор історичних наук, професор, головний науковий співробітник Інституту украӥнознавства НАН Украӥни ім. Івана Крип'якевича (м. Львів).

(C) Патер I. Г., 2021 
етапі становлення та формування національних військових частин як основи у побудові української армії для захисту своєї держави. Адже однією з головних підстав буття сучасної України є армія 3 високою національною свідомістю, готовою боронити за свою державу проти будь-якого ворога. Сьогодні ефективна і потужна протидія російській агресії на Сході країни вимагає від українського керівництва повної підтримки і подальшої розбудови Збройних Сил, а уроки минулого стосовно недооцінки місця і ролі армії у захисті державності не повинні повторитися, й стати повчальними для нинішніх державних діячів. Тому, вивчення військовополітичних аспектів діяльності СВУ зумовлює актуальність цієї наукової розвідки.

Аналіз попередніх досліджень. Вивченню найрізноманітніших аспектів діяльності СВУ присвячена чимала кількість наукових праць вітчизняних і зарубіжних вчених. Стосовно зазначеної проблеми, то іiі першими історіографами були безпосередні учасники цих процесів. Зокрема, національно-освідомлююча та культурно-просвітницька робота серед військовополонених українців у таборах Центральних держав висвітлена у публікаціях М. Гаврилка, К. Даниленка, В. Сімовича, В. Проходи, О. Охримовича, Р. Смаль-Стоцького, А. Глевкого, О. Скорописа-Йолтуховського, у збірнику спогадів «Союз визволення України. 1914-1918» Найбільш повно проаналізував просвітню працю Союзу в таборах полонених українців його активний співробітник О. Терлецький у своїй грунтовній монографії про діяльність Української громади у Раштаті в 1915-1918 pp.

Велику увагу приділяли діячі СВУ Українським січовим стрільцям, формуванню українських військових частин у таборах, ролі армії у захисті української державності. Ці питання відображено у роботах В. Дорошенка, Д. Дорошенка, О. Доценка, П. Дубрівного, Й. Мандзенка, М. Бутовича, В. Зелінського та ін. Діаспорна історична література представлена працями В. Вериги, В. Гришка, Р. Млиновецького. Є. Пастернака, а сучасна вітчизняна історіографія, стосовно військової діяльності СВУ - дослідженнями I. Срібняка, I. Патера, О. Сидоренка, І. Михальського, Р. Труби та ін.

Чимало матеріалів цієї теми почерпнуто з періодичних видань СВУ та інших українських часописів періоду Великої війни, а також з архівосховищ Києва, Львова та Оттави (Канада).

Мета наукової розвідки - з'ясувати ефективність національнополітичної та культурно-просвітницької праці СВУ в таборах 
полонених українців, проаналізувати вплив на їх свідомість революційних подій в Україні, висвітлити організацію українських дивізій.

Виклад основного матеріалу. Напередодні Першої світової війни відбулися помітні зміни в українському національному житті, зросли кадри свідомого громадянства, стрімко еволюціонізувала суспільно-політична думка, зміцнившись національно. Українці Галичини і Наддніпрянщини мали певні успіхи у національно-культурному житті, але незначні у національно-політичному. Ідеї державної самостійності і соборності все глибше проникали у національну свідомість українців, стали програмними у діяльності більшості політичних партій, а боротьба з царським режимом дедалі ширшала та міцніла серед української суспільності.

3 вибухом війни для галичан і наддніпрянців, які опинилися між двома ворогуючими країнами, змінилася національно-політична ситуація, а проголошення лояльності до своїх держав, під пануванням яких вони перебували, поставило їх у протилежно воюючі сторони. Тепер змагання за українську державність перейшло із загальнотеоретичної у конкретно-політичну площину.

Тому українці Галичини і Наддніпрянщини, що перебували в еміграції, зорієнтувалися в ситуації та взяли національно-політичну ініціативу у свої руки. Галичани у серпні 1914 р. організували Головну Українську Раду (ГУР) і почали створювати військові формації Українських січових стрільців, а наддніпрянці створили Союз визволення України (Патер, 2000:73). Ці триєдині чинники стали у війні на боці Центральних держав, захищаючи інтереси української нації, і були однією цілістю й дією, що кинули виклик найбільшому гнобителеві українців - Росії. Головна Українська Рада та Бойова Управа УСС закликали український народ: «До зброї! 3 оружжям в руках зміритися 3 віковічним ворогом - царизмом» (Діло, 1914). Український політикум добре усвідомлював, що здобути державну самостійність можна лише 3 допомогою збройної сили, яка змогла б поставити національну справу на порядок денний історії під час світової війни. Організувати власне військо стало для українців історичною необхідністю.

СВУ дуже прихильно поставився до створення першого українського військового формування - Легіону Українських січових стрільців. Він покладав великі надії на молоду армію, 
щоб не допустити зруйнування та поневолення рідного краю, вважав за необхідне організувати сильне, постійне й дисципліноване військо, перейняте найвищим національним ідеалом - самостійності Української держави.

Тому й були поставлені УСС як зразок національно-військової сили, щоб поряд із мільйонними арміями воюючих держав довести право українського народу на життя та власну державу. «По довгих роках летаргу (бездіяльності), - зазначав член Президії СВУ В. Дорошенко, - повстала збройна сила, своє власне українське військо, що рушило виборювати волю й долю рідному народові в кривавих змаганнях на полі бою» (Дорошенко, 1967: 39).

СВУ і Січові стрільці виходячи 3 національних інтересів хотіли втілити у життя прагнення галичан і наддніпрянців утворення незалежної соборної Української держави. В інформаційній брошурі «Відомості про російську Україну», підготовленій Союзом для Січових стрільців у серпні 1914 р. у Львові, а виданій у Відні в січні 1915 р., підкреслювалося, що «час слушний не відійшов, а наблизився до нас і день погибелі царської монархії та визволення України вже стоїть не за горами. Це мусить бути і це буде, бо ціла історія, все життя на нашім боці» (ЦДАВОВУ, ф. 4405, оп. 1, спр. 94, арк. 3).

У таємній директиві російського командування попри «зрадництво» Січовими стрільцями «великого общего дела освобождения угнетённых славян», підкреслювалося, що це добірне, 3 прекрасним бойовим вишколом військо, яке «називає себе українцями і хоче відновлення самостійної Малоросії. Наголошувалося, що більшість стрільців - це інтелігенти, які тісно пов'язані 3 Союзом визволення України (Доценко, 1934: 46).

Січові стрільці надзвичайно цінували і підтримували діяльність СВУ, вважали його працю цементуючою основою, на яку опиратиметься майбутня перебудова національного організму. Вони наголошували, що проголошена Союзом велика історична мета - державна незалежність і соборність України - для них перестала бути лише переконанням, «вона вросла в характер i душі наші, перейшла в діло, стала нервом нашого життя» (Святочні поздоровлення Січових Стрільщзів Союзови визволення України, 1915: 16).

Для СВУ Стрілецький чин був джерелом надії та оптимізму, особливо після переможного бою на Маківці в травні 1915 р. 
Успіхи УСС-ів на фронті давали Союзові переконливий матеріал у різних політичних і дипломатичних акціях. Стрільці, по суті, стали зародком національної армії, а 3 української справи, як зазначав член СВУ Роман Смаль-Стоцький, зробили міжнародну проблему (Смаль-Стоцьький, 1967: 93). Зрозуміло, що чин Українського стрілецтва обстоювали галицько-буковинський політичний провід і СВУ.

СВУ вважав, що воєнні успіхи стрільців, їх зміцнення стануть тим політичним чинником, який тільки посилить позиції українців у владних структурах Центральних держав. Але для того, щоб підтримувати бойовий дух стрілецтва, поповнювати його ряди, потрібні були резерви, які можна було взяти серед військовополонених українців у таборах Австро-Угорщини та Німеччини. Адже 3 вибухом війни кількість мобілізованих українців до російської армії, за різними методиками підрахунків, коливалися від 3,5 до 4,5 млн осіб, а в австро-угорському війську - від 250300 до 700 тис. осіб (Литвин, 2008: 396; Субтельний, 1992: 296). Зрозуміло, що чимала кількість вояків-українців у результаті боїв на фронтах потрапляла у полон. Так в Австро-Угорщині у лютому 1917 р. перебувало приблизно 1,1 млн полонених російської армії, в т.ч. до 200 тис. українців, а у Німеччині ще у жовтні 1918 р. нараховувалося 1,4 млн вояків російської армії, 3 них близько 300 тис. українців (Енциклопедія українознавства, 2000: 3121).

Тому вже на початковій стадії війни, наприкінці серпня 1914 р., діячі СВУ, перебуваючи ще у Львові, клопотали перед австроугорським командуванням надати їм доступ до полонених українців російської армії. Цю ідею підтримав й митрополит А. Шептицький. Проте тодішні події у Галичині не сприяли розв' язанню цієї проблеми (Патер, 2000: 274).

3 прибуттям на початку вересня до Відня СВУ звернувся до Міністерства закордонних справ Австро-Угорщини і наприкінці жовтня 1914 р. отримав згоду від військової влади держави щодо ведення національно-політичної роботи серед полонених українців 3 метою вибрати серед них якнайбільше національно свідомих (Library and Archives Canada (LAC). R-2297-0-3-E, Vol. 21, File 25).

Для полонених українців, які пройшли відповідний відбір через СВУ, були утворені окремі табори. Перший спеціальний 
табір для вояків-українців відкрито на початку листопада 1914 р. у містечку Фрайштадт (Верхня Австрія). Спочатку у ньому було дуже мало полонених, але 3 прибуттям 3 інших таборів взимку 1915 р. їх вже назбиралося 12 тис. чоловік. 3 переїздом до нього бдизько 5 тис. українців 3 табору Кніттельфельд (Штирія) навесні 1915 р. їх кількість зросла до 18 тис., а у 1917 р. у Фрайштадті разом зі старшинським табором у Йозефштадті (Богемія) нараховувалось 30 тис. полонених українців (LAC. R-2297-0-3-E, Vol. 15, File 25; Союз визволення України, 1979: 72; EУ, 2000: 3121). Крім того, в Австро-Угорщині знаходилися табори полонених українців у Дунасардегль (Словаччина) і старшинський у Терезієнштадті (Угорщина) (Союз визволення України, 1979: 52).

3 утворенням у квітні 1915 р. Централі СВУ в Берліні за дозволом Міністерства війни Німеччини близько 50 тис. українців виокремлено в табори полонених: Раштат, Зальцведель і Вецляр, а в 1917 р. у Ганновер-Мюнден, де перебувало 4 сотні старшинукраїнців (LAC. R-2297-0-3-E, Vol. 15, File 22; Патер, 2000: 277).

Для піднесення національної свідомості полонених українців СВУ створив у таборах Просвітні відділи, робота яких проводилась у трьох напрямах: а) загальна просвіта; б) національнопатріотичне виховання; в) навчання організації громадського життя. Виходячи з основних завдань національно-освідомлюючої та культурно-просвітньої праці Союз прагнув «створити 3 етнографічної маси полонених українців, що билися зі зброєю в руках у Першій світовій війні на всіх фронтах в обороні Російської імперії та потрапили до полону Австро-Угорщини та Німеччини, кадри національно-свідомих оборонців ідеї визволення України зпід московського поневолення» (Даниленко, 1979: 157).

Однак реалізовувати свою роботу щодо національного освідомлення полонених українців Союзові було нелегко. Адже вони, по-перше, піддавалися сильному тискові русофільства, у них ще існував страх перед російською владою за можливе колись притягнення їх до відповідальності навіть за пасивне ставлення до українства; по-друге, неприхильне, а то й вороже ставлення до австрійців і німців, пов'язане із самим фактом полону; по-третє, психічний стан полонених викликав у них критику, незадоволення, зневіру до всього і недовіру до інших. Національне почуття полонених тісно пов'язувалося з російською державністю та ідентифікувалося 3 нею у просторі «единства 
русского мира». Уявити собі, що українці та Російська імперія це зовсім нерівнозначні поняття, полонені не могли. Придушена царським режимом їх національна свідомість була низькою. В розмовах і суперечках полонені називали себе «хахлами», «малоросами», «руськими», «православними» і лише зрідка українцями. Тому національно-освідомлююча праця представників CВУ натрапила спочатку на значний опір з боку полонених. Тим більше, що їх підбурювали москалі, поляки, «малороси», різноманітними «люмпен пролетаріат» 3 великих українських міст. «За своїм світоглядом, - наголошував один із піонерів просвітньої праці у Фрайштадтському таборі, відомий український скульптор М. Гаврилко, - вони були чорносотенці та великі патріоти Московії» (Гаврилко, 1979: 7).

Однак завдяки наполегливій національно-освідомлюючій праці представники галицько-буковинських і наддніпрянських (з числа полонених) інтелігентних сил у таборах організовувалися школи, бібліотеки, читальні, хори, оркестри, освітні курси, театральні гуртки, будувалися церкви, засновувалися кооперативні заклади (крамниці, чайні, допомогові каси), видавалася таборова преса, утворювалися українські громади та спортивно-мілітарні товариства. Полонені пройшли велику еволюцію від несміливості та непевності у розумінні національної справи до усвідомлення себе українцями та великого зросту національної свідомості (Сімович, 1979: 94).

У зверненні бранця Раштатського табору А. Глевкого «До полонених українців!» наголошувалося на тяжких обставинах, у яких опинилися у цій війні українці, які однак дали їм можливість тільки зміцнити свою національну свідомість, право на яку має кожна нація. «Нехай же кожний, - закликав А. Глевкий своїх земляків, - стає свідомим українцем та піднесе сміливо перед цілим світом клич самостійності своєї нації. Минув вже час рабства!» (Глевкий, 1916: 1).

Зміцнення національних почуттів серед українських бранців тільки посилювало політичний бік української справи. Політичні питання посіли тепер провідне місце у національно-освідомлюючій праці СВУ. «І так поволеньки, - писав згодом В. Дорошенко, - спільними силами було виконане велике діло національного освідомлення й перевиховання полоненого вояцтва» (Дорошенко, 1954: 3).

Про піднесення рівня національної свідомості свідчили листи полонених до СВУ $з$ підтримкою його змагань за державну 
незалежність. Так фрайштадтці здобуття 22 червня 1915 р. австрійськими військами Львова відзначали як подію велетенської боротьби, яка високо піднесе прапор національних домагань, закладе підвалини подальшого успіху, вірили, що і «на закордонній Україні (Наддніпрянщині) зацвіте квітка волі та національної праці». Раштатці бажали Союзові довести до кінця розпочату справу визволення України, сподівалися, що «правда переможе і незабаром засвітить сонце на рідній Україні» (Патер, 2000: 284).

Українізація таборів, незважаючи на всілякі труднощі, протягом 1916 року обумовила велетенський крок уперед. Національна справа дедалі більше охоплювала бранців, які зрікалися своїх «малоросійських» переконань і ставали «в ряди справжніх борців за долю України, щоби прийти перед очі українського громадянства 3 ясними очима, 3 чистою совістю. У статті «17.І.1917» полоненого Зальцведельського табору під криптонімом Ф. Я. наголошувалося: «Нехай між нами не буде ні «малоросів», ні «хахлів», а будуть справжні українці, борці за волю Вітчизни, гідні називатись правнуками «славних прадідів великих». Скоріше ж несвідомі освідомлюйтесь, а свідомі несіть свої сили «меншим братам», аби на нашу совість не впав докір будучих поколінь i, щоби назавжди змили зі свого чола печать рабства. Боротьба відверта, щира, свідома, завзята боротьба приводить до осягнення бажаних цілей...» (Ф. Я., 1917: 1).

Таким чином, широка національно-освідомлююча робота Союзу серед полонених напередодні революційних подій в Росії та Україні призвела до того, що з невиразної сірої маси повстав свідомий український громадянин, як писав В. Сімович, «який ось-ось має вхопитися за дишель свого воза й кермувати ним, як цього йому треба» (Сімович, 1939: 57).

У листі полонених українців Вецлярського табору до СВУ від 20 січня 1917 р. говорилося: «Ми серцем відчуваємо, що надходить великоважний історичний момент для України і глибоко віримо, що недалекий вже час, коли на руїнах царської імперії, цієї тюрми народів, зійде сонце Вільної України!» (До Союзу визволення Украӥни, 1917: 1).

Звістка про революцію в Росії, отримана полоненими українцями 15 березня 1917 р., започаткувала нове життя у таборах, яке віддзеркалювало всі тогочасні події на Сході Свропи, стала для українських бранців духовним визволенням. Тепер вже ніхто 3 
них не боявся, що, повернувшись 3 неволі, відповідатиме перед владою за своє українство.

Полонені українці в Австро-Угорщині та Німеччині з великим піднесенням сприймали події російської революції. Табори військовополонених українців - Фрайштадт (Австрія), Раштат, Зальцведель. Вецляр (Німеччина), Дунасардагель (Угорщина), об'єднуючись з українськими робітничими командами, на своїх зборах приймали резолюції та петиції, в яких зверталися до Тимчасового уряду і революційних діячів 3 вимогою негайного повернення українському народові його національних прав. Ці політичні звернення полонених українців майже всюди були 3 однаковими вимогами: покласти в основу нових законів повне народоправ'я, провести земельну реформу на користь українського селянства, укласти мир, відновити українському народові всі національні права до Переяславської ради 1654 р., знищені російським царизмом (ЦДАВОВУ, ф. 4405, on. 1, спр. 182, арк. 1-2).

Варто зазначити, якщо Фрайштадт у своїх вимогах не виходив поза рамки національно-територіальної автономії України, з'єднаної з Росією, то полонені німецьких таборів по-іншому реагували на це. Вони провели дискусію 3 цих вимогам фрайштадтців і у них виникли сумніви, чи можна тепер вже задовільнятися Переяславом. (Сімович, 1937: 75). Полонені вважали, що Переяславський договір 1654 р. був основою відносин України 3 Росією у XVII столітті, а тепер він не годиться, а щонайменше мусить бути підданий грунтовній ревізії, щоби українському громадянству «необкроєне володіння своїх національних прав» було як слід забезпечено вимогами життя в XX столітті.

Полонені українці прагнули 3'ясувати своє місце у революційних подіях, зрозуміти свою роль і вагу в цих процесах. «В ім'я чого й за кого маємо, ми, українці, класти й далі свої голови? Перше, за князів Романових, а тепер за князів Львових, Мілюкових та Родзянків? Знімати останню одежину, щоб сплачувати англійцям, французам і будь-яким іншим зайдам борги, що наробив деспотичний уряд? - заявляли полонені. - Українське громадянство нічим не зв'язано супроти російського уряду. Він $\epsilon$ чужий для нас, а ми для нього. Нас не повинна зваблювати думка, що, коли Росія стане республікою, то вже для нас настане раювання, по-перше, ми не знаємо, чи буде республіка, а по-друге, коли б вона й стала республіканською державою, то хіба не 
заправлятимуть нею такі самі бюрократи, як i при Миколі Романову, хіба тільки в іншій одежі» (Патер, 2000: 291).

Отже, після початкової революційної ейфорії до полонених приходило протверезіння, розсудливе оцінювання ситуації, що українцям потрібно бути напоготові, бо ж $з$ проголошення волі після першої революції 1905 р. Україна нічого не скористала. Тому полонені Зальцведельського та Вецлярського таборів наголошували, що «тільки своя незалежна держава дасть повну свободу, тільки в ній забезпечений розвиток народу - тим-то нам треба самостійної України, іiї нам треба добиватися», а для цього «треба використати час полону на те, щоб приготовитись до боротьби за самостійну Україну, й до того, як треба самостійність будувати та ії вдержати» (Сімович, 1937: 74).

Зазначимо, що після довгих нарад полонені німецьких таборів вирішили все ж таки підтримати і прийняти ухвалу фрайштадців стосовно Переяславської умови, вважаючи ці домагання тільки перехідними, а різні розходження могли б тільки зашкодити українській справі. Розуміючи, що до їх голосу на чужині російська влада не дослухається і вони не зможуть скористатися своїм правом участі в політичному житті краю, голосно заявити, які порядки повинні бути заведені на Україні, полонені вирішили передати свої домагання Тимчасовому урядові в українській справі у формі мандату членові Президії СВУ О. СкорописовіЙолтуховському. Вони разом з СВУ уповноважили його їхати до Петрограду для переговорів 3 новим московським урядом про права українського народу, щоб «у нашій хаті стала вже раз і назавше наша правда!» (До всіх громадян Зальцведельського табору, 1917: 1).

У мандаті підкреслювалося, що загальноросійські Установчі збори ні в якому разі не повинні вирішувати долю України. Українське питання на міжнародному рівні, національне i політичне життя України, iї відносини 3 Росією та іншими державами повинні розглядати тільки Українські Установчі збори в Києві, які мають бути скликані на підставі загального, рівного, безпосереднього i таємного голосування, проведеного на території, заселеній українським народом (Мандат президентові Союзу визволення України добродієві Олександрові СкорописуЙолтуховському, 1917:1). Під домаганнями або мандатом полонених у всіх українських таборах Австро-Угорщини та 
Німеччини до 1 травня 1917 р. підписалися 19004 чоловік, у т.ч. 39 офіцерів-українців (Терлецький, 1918:347).

Перша конференція представників українських таборів у Німеччині (по 5 від Раштата, Вецляра, Зальцведеля і члена Президії СВУ О. Скорописа-Йолтуховського), яка відбулася 7-8 травня 1917 р. у Зальцведелі засвідчила, що 20 тисяч підписів під Мандатом незважаючи на численні перешкоди стали гарним доказом високої свідомості полонених українців. На конференції відбулася принципова дискусія про ставлення українців до тодішньої післяреволюційної ситуації в Україні, до тогочасних світових політичних подій. У прийнятій з цього питання резолюції наголошувалося: «Конференція стверджує, що революція в Росії не змінює зовсім нашого основного ідеалу повної державної самостійності українського народу та, що основою нашої діяльності, як і дотепер, є якнайширша організація свідомих мас українського народу» (Периа українська конференція в Німеччині, 1917: 1).

Національно-освідомлююча праця в таборах проводилася в дусі тодішніх політичних подій в Україні. Надзвичайно піднесено зустріли полонені українці проголошення автономії (23 червня 1917 р.) I Універсалом Центральної Ради, яку вони вважали своїм урядом, схвалювали іiі діяльність, запевняли у своїй відданості. Варто зазначити, що не у всіх таборах політичні настрої полонених були однаковими. Раштат, наприклад, був більш соціалістичним, хоч за суттю українським, в якому «перероблювано малоросів i хохлів на свідомих українців». Проте у прийнятій ухвалі таборних зборів від 25 червня 1917 р. $з$ нагоди проголошення I-го Універсалу не було й мови про незалежність України, а вислів «Вільна Україна» по-своєму трактували самостійники й автономісти. «Одне було певне, - писав О. Терлецький, - що Центральна Рада мала симпатію у Раштатськім таборі» (Терлецький, 1918: 152, 356).

Зате у Зальцведельському і Вецлярському таборах скрізь був дух український, самостійницький, незалежницький. «Радуйтеся зморені муками усі діти України: над Києвом повіває зі святої Софії жовто-блакитна хоругва вільної Української республіки! підкреслював вецлярський часопис Громадська думка. - Діждали ми такої радості, якої не було від часів Богдана... 3 вибухом революції в Росії піднялася Україна на весь ріст; всі свідомі згуртувалися без різниці партії і стану в один великий гурт i станули одною лавою до великого діла... Щасливішої хвилі, 
як теперішня, не найде Україна вже ніколи, то тепер слід нам за всяку ціну здобувати державну незалежність» (Золотий вінець Украйни, 1917: 1).

Тодішні національні почування і державницькі домагання українців надзвичайно вміло виразив своїм поетичним словом у вірші «Спів товпи» Василь Пачовський, який у роки війни проводив культурно-освітню працю у Вецлярському таборі:

...Від Кавказу по Сян лиш один буде лан,

Його власником - нарід цілий.

Спільна праця і край, блисне воля і рай -

України вінець золотий! (Золотий вінець України, 1917: 1).

Полонені українці у таборах Центральних держав складали присягу Центральній Раді, збирали кошти на Український національний фонд. Так організація українців табору Дунасердагель 2 травня 1917 р. передала через СВУ для цілей фонду 30, полонені Фрайштадту - 338, а офіцери-українці з Йозефштадту - 120 корон (ЦДАВОВУ, ф. 4405, оп. 1. спр. 176, арк. 22, 31; Полонені на Украӥнський начіональний фонд, 1917: 399).

Варто зазначити, що після проголошення III Універсалом Центральної Ради (20 листопада 1917 р.) Української Народної Республіки (УНР) полонені українці Фрайштадтського табору повністю відкинули свої автономістичні погляди і обрали шлях цілковитої державної незалежності. У своєму зверненні до Центральної Ради від 24 грудня 1917 р. вони наголошували, що живуть виключно всіма пережиттями України, страждають від покривдження і несправедливості з боку московського уряду та централістичної демократії, ворожого ставлення центральної влади нової Росії до найсправедливіших домагань українського народу, обмежень території України та прав Центральної Ради і Генерального Секретаріату, шпигунського нагляду за їх діяльністю та спроби притягнути їх до судової відповідальності за провокаційні виступи проти українізації армії, полуботківців і богданівців, і нарешті, замах на саме існування Української Народної Республіки. Все це викликало надзвичайно велике незадоволення й обурення у фрайштадтців. «Тепер полонені українці, вірні сини Української Народної Республіки, - підкреслювалось у зверненні, - 3 великою нетерпеливістю ждуть того щасливого часу, в який мають повернутися додому, щоб стати в міцні лави оборонців народно-республіканського ладу на 
Вільній Україні». Звернення підписав голова Іван Мороз і 20 членів Головної Української ради табору Фрайштадт (Солдати-украӥниі украӥнського табору у Фрайштадті в Австрії до Украӥнської Центральної Ради, 1918: 18).

Для консолідації національних сил 17-20 вересня 1917 р. у Раштаті була скликана міжтаборова конференція Українських громад Зальцведеля, Вецляра і Раштата, метою якої стало обговорення тогочасного політичного становища та напрями подальшої роботи. На конференції прийнято низку ухвал: 1) у справі ставлення до тодішнього політичного моменту ії учасники визнали постулат повної незалежності українського народу. Для реалізації цієї мети слід впроваджувати якнайширшу організацію мас у всіх ділянках національно-політичного життя українців; 2) для закріплення здобутків українського народу добиватися якнайшвидшого укладення миру; 3) Центральну Раду до часу скликання Українських Установчих зборів визнати єдиним краєвим представництвом України, висловити їй повну довіру і допомогу; 4) зимову роботу по таборах вести, якщо можливо, у ширших масштабах, використовуючи місцеві взаємини кожного табору, робити міжтаборові обміни організаторських і викладацьких сил, вести взаємодопомогу; 5) домогтися дозволу на відвідування неукраїнських таборів задля переведення до українських інтелігентів-українців; оголосити через таборові часописи заклик до українських інтелігентів зголошуватися до громадської роботи в українських таборах; 6) для підготовки народних вчителів утворити вчительські курси; обладнати мандрівний театр; 7) якнайшвидше скликати з'їд делегатів видавничих товариств і налагодити справу видання одного щоденного українського часопису в Німеччині замість 3-х таборових газет: зальцведельської - «Вільне слово», вецлярської - «Громадська думка» і раштатської - «Розсвіт» та унормувати видання книг (Конференція українських таборових організачій в Німеччині, 1917: 712).

Варто зазначити, що велика національно-просвітня праця СВУ серед українських бранців приносила свої результати. Про це свідчив факт висилки у липні 1917 р. з Фрайштадту в Україну через «Червоний Хрест» у Стокгольмі 17 свідомих українців як агітаторів за українську державність для допомоги Центральній Раді у національно-пропагандистській роботі. Однак через донос одного полоненого українця - вчителя з Сибіру у Петрограді всіх 
ïх було заарештовано як «німецьких агентів» i посаджено у в'язницю «Кресты», де їх допитували. Тільки за допомогою представника Центральної Ради у Петрограді Петра Стебницького через місяць усіх було звільнено (Даниленко, 1979: 26-28).

Союз надавав великого значення проведенню національнопатріотичної роботи серед полонених офіцерів-українців царської армії, які утримувалися окремо від солдатського складу у невеликих спеціальних таборах 3 відповідними умовами перебування та самоуправління. Однак консервативність офіцерського корпусу довший час перешкоджала організації старшинських таборів. За 1915 -1916 рр. до української справи приєдналося лише декілька офіцерів українського походження та за переконаннями (Срібняк, 1996: 6). Проте революційні події в Росії та Україні дали відчутний поштовх до утворення українських гуртків і організацій не тільки у таборах військовополонених рядового складу, а й у офіцерських.

Одним із перших почав українізовуватися табір у Терезієнштадті. Хоч у таборі переважали російські настрої, проте молодші офіцериукраїнці заснували декілька гуртків - драматичний, хоровий, бібліотечний, кооперативний, руханково-спортивний «Сокіл». Заснований прапорщиком Костем Курилом «Кружок членов Малорусской библиотеки», діяльність якого завдяки тісному зв'язку 3 Андрієм Жуком (членом Президії СВУ) та поширенню періодичних видань - «Вістника СВУ» і фрайштадтської «Розваги» мала значний вплив на піднесення культурно-просвітньої роботи у таборі. Число членів українського гуртка в Терезені збільшилося 312 до 50 осіб (Прохода, 1978: 54).

У петиції до Тимчасового уряду полонені офіцери-українці цього табору (всього 12 підписів) вимагали перетворення Росії на федеративну республіку, в якій «український народ, ціла українська земля дістане запоруку повної самоуправи» (Група полонених офічерів-українців табору Терезієнштадт, 1917: 269).

Значний вплив на пожвавлення українізації табору мало утворення Центральної Ради. Офіцери-українці, бажаючи долучитися до справи розбудови українського життя, за порадою Президії СВУ звернулися до воєнного міністерства АвстроУгорщини 3 проханням перевести їх до Фрайштадту. Однак в офіційній відповіді зазначалось, що офіцерам не дозволено перебувати у солдатських таборах. Тоді заходами СВУ був українізований старшинський відділ табору полонених у Йозефштадті із заміною в ньому російських офіцерів українцями (Прохода, 1979: 54). 
Важливу роль для створення старшинського підрозділу в цьому таборі відіграло «Звернення до українських офіцерівполонених», опубліковане СВУ 18 травня 1917 р. Союз закликав усіх офіцерів, уродженців України, які підтримували зв'язки і мали намір після війни далі жити у краї, зголошуватись до табору щодо вироблення програми дій для майбутньої практичної громадської праці в Україні після повернення додому.

На початку червня 1917 р. до Йозефштадту прибуло 20 офіцерівукраїнців, а через місяць ще стільки ж на місце вивезених росіян. Також почали прибувати українці 3 офіцерських таборів Гарт, Браунаув, Мархтренк, Кляйн-Мюнхен, Мюлінг, Мост (Брюкс), Ліберець (Райхенберг), Візенбург. 3 усіх старшинських таборів Австро-Угорщини Йозефштадт був найменший, нараховував лише 120 офіцерів, тому він найлегше піддавався українізації. Адже в ньому досить легко було зосередити офіцерів-українців замість виселених в інші табори росіян.

У таборі незважаючи на велику ворожість і ненависть до українства переважно штабних офіцерів, ще в 1915 р. виник і діяв нелегально «Український гурток», що нараховував 15 чоловік, ядро якого складали хорунжі Яків Сич і Микола Букшований, підпоручник Малевич, капітан Петро Ганжа та підполковник Іван Перлик (Прохода, 1979: 54).

На установчих зборах 17 червня 1917 р. «Українського гуртка табору Йозефштадт» були присутні 26 його членів-засновників, обрана рада гуртка: голова - П. Ганжа, заступник - Д. Скарженовський, скарбник - М. Букшований, книгар - Я. Сич, писар В. Прохода. Члени гуртка проводили роботу в суто національному дусі: читали лекції на українознавчі теми, зокрема про національновизвольну боротьбу українського народу за незалежність, українське питання у міжнародних відносинах, розвиток українського суспільства на засадах демократії, видавали стінний тижневик «Наш голос», діяла бібліотека під керівництвом К. Курила, яка у грудні 1917 р. нараховувала 1,5 тисячі книг (Мандзенко, 1956: 8).

У таборі щотижня відбувалися політичні віча, на яких обговорювали події в Україні та національний рух у військових частинах російської армії. 3 радістю вітались постанови Всеукраїнських з'їздів та I Універсал Центральної Ради про національно-територіальну автономію України. У «Привіті українському народові й Українській Центральній Раді» від 
1 липня 1917 р. полонених офіцерів-українців табору Йозефштадт підкреслювалося: «...Сини Твої на чужині в тяжкій неволі пильно стежать за Твоєю долею, болять Твоїми болями й радіють Твоїми радощами... горді за своїх борців, які так високо піднесли прапор Вільної України і вже твердо стоять на сторожі наших прав... займай на всіх полях широку займанщину, - підмога йде! Велика армія полонених українців незабаром повернеться додому, дасть великі кадри робітників і буде боронити нашу волю!» (Полонені офіиери-украӥниі до Центральної Української Ради, 1917: 541).

Однак проголошення II Універсалу Центральної Ради 16 липня 1917 р. (зобов'язувалися перед Тимчасовим урядом не робити самовільних кроків до здійснення автономії України) спричинило сильне невдоволення офіцерів-українців Йозефштадту, а ще більше роздратування викликав розстріл російськими кірасирами вояків Богданівського полку 8 серпня 1917 р. у Києві. 3 цього приводу йозефштадтська громада офіцерів-українців висловила 12 серпня 1917 р. свій протест і глибоке обурення за злочинний напад на козаків-богданівців та вшанувала «пам'ять славних оборонців Рідного Краю, що полягли від рук темних сил» (Протест полонених украӥнців-офіцерів табору Йозефштадт у Чехах проти розстрілу богданівців, 1917: 654-655).

27 серпня 1917 р. Управа офіцерського табору полонених у Йозефштадті видала відозву «До полонених офіцерів-українців». Ця відозва характерна тим, що вона засвідчила швидке зростання рівня національної свідомості старшинського складу, розуміння ним ситуації, в якій опинилась Центральна Рада, проголосивши II Універсал, щоб не ускладнювати відносин 3 Петроградом, підкреслювала внутрішнє відчуття офіцерами-українцями різкого розходження шляхів російської й української демократії, їхнє бажання $з$ поверненням додому допомогти українському керівництву творити національні форми влади і суспільного життя.

Актуально у той час звучали слова у зверненні щодо необхідності побудови нового ладу в Україні, а для цього потрібно велику кількість національної інтелігенції, «багато робітників - свідомих українців, не тільки по назві, але й по духу». Злободенною для сьогодення була у відозві така думка: «Той, хто не знає своєї мови, літератури, звичаїв свого народу, відноситься до них байдужно, немає права називатися українцем, то буде якийсь недошкребок культури. Такому не місце в сім'ї 
вольній, новій». Ще більш ближчим до сучасності був погляд полонених офіцерів на будь-яку протекцію у здобутті «тепленької посади», адже «всі уряди мають бути виборні». Вони застерігали: «Це хай пам'ятають ті, хто дивиться на життя з боку практичного, матеріального».

Йозефштадтці зверталися до полонених інших таборів «підготовити себе до праці серед свого народу», бо, повернувшись додому, «будемо мати багато роботи. Там ніколи буде учитися, а тут маємо вільний час і повинні його використовувати... Наша мета стати свідомими громадянами Вільної України... змити з себе геть той намул русифікації». Вони звертались до полонених офіцерівукраїнців, «хто почуває себе сином України, хто не ворог свого народу, хто хоче стати свідомим громадянином», подавати рапорти для переведення до Йозефштадту.

Закінчувалася відозва закликом до земляків: «Товариші! Просніться, порвіть кайдани, які наложила московська урядова культура на ваші душі, ваш розум, вдихніть в себе хоч трохи вільного повітря. Не цурайтесь вільного рідного слова, - воно має творчий дух! 3 рабів воно робить вільних громадян. Дізнайтеся нарешті, хто ви, яких батьків і чиї сини. Гуртуйтесь, працюйте!» (До полонених офічеерів-українців, 1917: 691-692).

Остаточно українізація старшинського табору Йозефштадт завершилася призначенням австрійською адміністрацією його комендантом сотника австрійської армії Степана Томашівського. 3 його ініціативи в кінці жовтня 1917 р. медична комісія визнала 7 старшин-українців «напівінвалідами» 3 метою висилки їх в Україну для інформації українського керівництва та громадянства про діяльність полонених українців в австрійських таборах та їх самостійницькі настрої. Тоді обмін полоненими між Росією й Австрією проводився через нейтральну Швецію. Однак на перешкоді цьому став більшовицький жовтневий переворот. «Інваліди» були зібрані у пересильному таборі Мост (Брюкс), де просиділи безцільно до травня 1918 р. і тоді виїхали до Києва (Прохода, 1979: 55).

У Йозефштадті 3 радістю підтримали III Універсал (20 листопада 1917 р.) і проголошення Української Народної Республіки. Президія Управи табору за підписом голови підполковника I. Перлика, заступника - прапорщика Я. Сича i писаря - М. Букшованого прийняла 12 грудня 1917 р. звернення 
до Центральної Ради. У ньому, зокрема. підкреслювалося: «...сподіявся акт величезного значення. Відтепер політичне, національне, культурне й економічне життя піде своїм природнім шляхом, відповідно вдачі нашого народу». Українські бранці сердечно вітали своїх наддніпрянських братів, що «збили кайдани неволі з нашої України», наголошували на їх велетенській праці, яка стала «не тільки внеском у духовну і матеріальну скарбницю України, але й вкладкою на користь вселюдського поступу». Йозефштадтці зазначали у проголошеній УНР велику роль Центральної Ради і Генерального Секретаріату, які «утворили маяк, що ярко світить тепер усім поневоленим націям, і компас, на котрому привели народній корабель серед бур, скель і туманів до мети, котра означає нову добу в історії Європи» (Офічери-українці табору Йозефитадт у Чехах до Української Центральної Ради. 1918: 17-18).

Українські громади були створені полоненими офіцерами й у інших таборах. Так у Райхенбергу (Чехія) влітку 1917 р. створено українське земляцтво «Громада полонених офіцерів у Райхенбергу», яка нараховувала 30 членів, а ії діяльністю керувала управа на чолі 3 I. Гораком i секретарем А. Шпоновським. Товариство завдяки допомозі СВУ мало власну бібліотеку і читальню, кілька разів на тиждень влаштовувало історико-літературні виклади і читання. Його члени навчали всіх бажаючих української грамоти, показували театральні вистави, організовували дискусії на суспільно-політичні теми (Украйнське земляитво «Громада полонених офіцерів у Райхенбергу в Чехах», 1918: 17-18).

Існував також український гурток у таборі Мархтренк (Верхня Австрія), при якому діяла чимала книгозбірня $з$ творами класиків української літератури та різними тогочасними українськими часописами. У лютому 1917 р. був утворений у таборі Естергом (Угорщина) український гурток у складі трьох офіцерів-українців, які почали проводити 3 солдатами бесіди патріотичного змісту. Чорносотенці називали їх «ізмєннікамі», а «малороси» - «виродками нації, котрі не мають нічого спільного $з$ народом, а служать тільки австрійському війську». Тільки після лютневої революції дехто 3 офіцерів став прихильніше ставитися до української справи, і український гурток поступово збільшився до 20 осіб. А при складанні списків до українського війська це спонукало значну частину офіцерів з малоросійськими переконаннями зголоситися 
до нього, хоч вони і не думали служити Україні. Так із 167 офіцерів, які перебували в таборі Естергом, 110 осіб подали свої прізвища до списків, мотивуючи це тим, що до війни вони служили в Україні. Після втручання у процес складання списків голови українського гуртка прапорщика Пархотюка фігурувало вже 67 офіцерів, які походили $з$ України, здебільшого 3 цього середовища було дуже багато добрих українців. Однак і серед них були особи без стійких національних переконань, які «пливли за течією» і наважувалися на рішучі дії лише після доленосних політичних подій в Україні (Срібняк, 2019: 232-233).

Загалом полонені офіцери-українці завдяки національнопросвітницькій праці СВУ пройшли велику школу українства, про що свідчили їхні численні звернення про підтримку Центральної Ради, їхнє бажання активно включитися у громадську роботу після повернення додому, стати гідними працівниками у побудові та захисті нового ладу в Україні.

У Німеччині активно діяла Українська громада старшинського табору у Ганновер-Мюндені, яка нараховувала 120 осіб. У iї заклику до полонених офіцерів у Німеччині від 15 грудня 1917 р. наголошувалось на повній довірі Центральній Раді, основними політичними принципами якої керується у своїй роботі табірна громада. Підкреслювалось, що на рідній землі проводиться велетенська робота - відбуваються різні з'їзди, закладаються нові інституції, росте організація краю, повстає народна влада, будується міцний грунт для життя одноцільної, незалежної й вільної, демократичної України. «Та революція ще не скінчилась, - зазначалося у заклику, - ще чується подих шаленої реакції. Народна свобода й добробут ще не закріплені. Але вони $є$ в руках самого народу. Лише організація, тісне з'єднання всіх синів України та спільна невпинна праця приведуть нас до осягнення повної волі».

Офіцери-українці звертались до інтелігенції вмконати свій обов'язок перед рідним краєм і народом, тому потрібно вчитися, допомагати один одному, гуртуватися, щоб бути підготовленими до дійсности, до безмірно широкої праці на народній ниві.

Українська громада офіцерів Ганновер-Мюндену закликала всіх, хто хотів набути собі на майбутнє знання і досвід у громадській роботі і бути дійсно корисним для свого народу, подавати рапорти на переїзд до табору. 
Відозву за Українську громаду табору підписали: генералмайор В. Зелінський, підполковники Пухтаєвич і Коваленко (До всіх полонених офіџерів-українців у Німеччині, 1917: 839-840).

Після проголошення Четвертго Універсала УНР (22 січня 1918 р.) державної незалежності українського народу полонені старшини-українці Йозефштадту звернулися 5 лютого 1918 р. до комендатури табору 3 заявою: «3 огляду на доконаний факт признання України незалежною, вільною й суверенною державою ми, нижчепідписані офіцери-українці і приналежні до сеї станції солдати, заявляємо, що від цього моменту лічимо себе офіцерами й солдатами Української національної армії, прохаємо Ц[ісарську] й К[оролівську] Команду станції пробити негайно по телєграфу заходи перед компетентними властями, щоби нас у порозумінні з правительством Української Республіки офіціально було признано до українського війська». Відповідно до поданого списку бажання вступити до армії УНР виявили 132 українці, серед них 97 старшин і 35 солдатів (Центральний державний історичний архів Украӥни у Львові, ф.368, оп. 1, спр. 79, арк. 3-5).

Після підписання Берестейського мирного договору між незалежною Україною і державами Почвірного союзу на заклик уряду УНР в таборах полонених українців почали формуватися українські військові відділи. Підгрунтям для них стали спортивні товариства «Січ», навколо яких згуртувалися найбільш національно свідомі вояки-українці, готові зі зброєю в руках виступити на захист рідного краю. Такі організації були у всіх українських таборах полонених Австро-Угорщини та Німеччини (Срібняк, 1996: 14-25).

Полонені українці вважали за обов'язок захищати права свого народу, виступали за необхідну і негайну потребу організувати всіх національно свідомих елементів у найміцнішу дисципліновану українську армію. «Чого не зроблено в минувшині, те треба конче наздогнати в теперішньості й будучині, - підкреслювали фрайштадтці, - бо тільки сильна, на європейський зразок зорганізована українська армія може захистити здобутки революції й повну самостійність держави українських трудових мас, Української Народної Республіки» (Периі роковини Української Центральної Ради, 1918: 186).

Вже 9 лютого 1918 р. у Фрайштадті згідно з ухвалою таборової організації - Головної Української Ради приступили до 
організації полку імені Гетьмана Петра Дорошенка, згодом перейменованого у «І-й фрайштадтський курінь Оборони рідного краю». Для цього утворено спеціальний комітет - Бойову Управу. 3 прибуттям 22 лютого 1918 р. 3 Йозефштадту 5 старшин-українців на чолі з капітаном П. Ганжею Бойова Управа зуміла в короткий термін зорганізувати перший транспорт з понад 900 добровольців, який вже 1 березня виїхав до Володимира-Волинського (Організація частин украӥнського війська з полонених у таборі Фрайштадт $i$ вимари І-го куреня на Україну, 1918: 160-161).

До Президії СВУ та Головної Української Ради Фрайштадту надходили заяви і цілі списки полонених з інших таборів, зокрема 3 Дунасардагеля, Шпрацерна, Тухлі, Зальцербада, Лібрінга, 3 робітничих команд, які добровільно зголошувались до українського війська. Всі заяви, по суті, були ідентичні. Наприклад: «Ми, нижчепоіменовані полонені українці робітничої команди з Темешварі на Угорщині, отримавши вістку, що формуються полки, які стають проти більшовицьких банд, звертаємось до Вас 3 проханням якнайскоріше перевести нас до Фрайштадтського табору, щоб і ми могли стати в лави борців за волю і свободу нашої Української Республіки» (ЦДАВОВУ, ф. 4405, оn. 1, спр. 179, арк. 6, 10, 74, 98-128; спр. 208, арк. 5-6).

Зголошувалися про переведення до Фрайштадту офіцериукраїнці 3 інших таборів: 3 Райхенбергу виявили бажання 22 офіцери, 3 Мархтренку старшини Горшковський, Максай і Демідов 11 березня 1918 р. просили допомогти з переведенням до українського табору, бо їх колеги вже виїхали до ВолодимираВолинського. а вони 3 незрозумілих причин продовжували залишатись у ворожому оточенні. Полонені офіцери-українці М. Лисий, В. Тарновський, К. Кравченко, О. Леонтович, I. Скучар-Скворовський з табору Варошзалонок з Угорщини у листі до СВУ від 5 березня 1918 р. також висловили бажання «стати в ряди оборонців Рідного Краю» і перевести їх до Фрайштадту (Срібняк, 2019: 233).

Такі заяви, які щоденно надходили до СВУ й української організації у Фрайштадті, засвідчували розуміння полоненими своїх завдань перед Вітчизною у тяжкий для неї період, тому не можна було мати найменших сумнівів, що армія, складена 3 таких свідомих одиниць, сповна виконає не тільки свій громадянськовійськовий обов'язок, але й інші завдання для волі i добра українського народу. 
Бойова Управа табору Фрайштадт у короткий термін сформувала ще кілька транспортів добровольців, яких щоденно прибувало по 200-300 чоловік, і перевезла їх до ВолодимирВолинського. Подальшу реорганізацію та вишкіл новоприбулих добровольців здійснювали австрійські інструктори на чолі 3 капітаном австрійського генштабу П. Кватерником, який деякий час був начальником штабу Легіону УСС. Інструкторами при вишколі здебільшого були старшини і підстаршини галичани, серед них сотники I. Коссак, М. Луцький, I. Стельмах, I. Слюсарчук, поручник - М. Хронов'ят, хорунжий М. Гаврилко, військовий лікар Воронич та ін. Німці та чехи були інструкторами при організації рахунково-господарської справи (Бутович, 1966: 22). Варто зазначити, що взаємини між наддніпрянцями і галичанами в той час були якнайкращими, адже усіх об'єднувала одна мета - відродження незалежної України.

3 прибуттям 13 березня 1918 р. до Володимира-Волинського 30 старшин 3 Йозефштадту був сформований штаб майбутньої Першої стрілецько-козацької української дивізії. Командиром дивізії призначено підполковника І. Перлика. Начальником штабу 3 австрійського боку П. Кватерника і $з$ ним його ад’ютанта і радника сотника I. Коссака, з українського - паралельно сотника (капітана) Пилипенка і ад'ютантів або значкових-старшин (підпоручника) М. Бутовича та (підпрапорщика) Горбика. Командиром полку став сотник (капітан) П. Ганжа (Бутович, 1966: 21).

На початку травня 1918 р. кількість прибулих з Фрайштадту до Володимира-Волинського добровольців-козаків збільшувалася. 12 травня 1918 р. I Стрілецько-вояцький полк піхоти розгорнуто у Першу Стрілецько-Козацьку дивізію (Сірожупанників) у складі чотирьох піхотних і гарматного полків, інженерної сотні та кінного дивізіону. Крім того, дивізія мала валки (кавалькаду возів), шпиталь та допоміжні майстерні (шевську, збройну) і хлібопекарні. Піхотний полк складався 3 3-х куренів по 4 сотні в кожному й кулеметної сотні. Командиром дивізії залишався I. Перлик, а іiі штаб був доповнений відповідними українськими i австрійськими референтами. Командирами полків призначено: 1-го - сотника Ганжу, 2-го - полковника Тимошенка, 3-го - сотника Яковтева, згодом підполковника Александровича, 4-го - сотника Ткаченка. На 1 липня 1918 р. бойовий стан дивізії складав 140 старшин і 6000 козаків. 
Старшинам доводилось докладати чимало зусиль, щоб виховати свідомого й дисциплінованого українського вояка. Не всі прибулі добровольці витримували суворий режим, напружену цілий день муштру, практичні й теоретичні вишколення або національноосвідомлюючі заняття. «Певний відсоток колишніх полонених, згадував у своїх спогадах колишній сотник Армії УНР М. Бутович, не витримували такого режиму, та й харчі на початках були недостатні. Тому стала була, хоч і невелика відсотково, але помітна дезерція (дезертирство). А втім полова відсіювалася від свідомого зерна».

Серед старшин була чимала кількість відомих українофобів, яких одразу відправляли назад у табір. Не потрапила до дивізії й певна частина відомих старшин-українців - некадрових офіцерів через боязнь, що з поверненням в Україну вони повернуться до своїх колишніх професій і тоді військо залишиться без командирів. «Але потрібно ствердити дивне явище, - підкреслював М. Бутович, що революція й самий факт існування УНР зробили у багатьох колишніх українофобів психічний переворот. Раз вступивши до дивізії, вони як ті Савли, що ставали Павлами, залишилися вірними Україні до кінця» (Бутович, 1966: 24).

Зазначимо, що формування українських військових частин відбувалося у період величезного загального духовного піднесення, але, на жаль, не було до кінця витримане в організаційному плані, зокрема щодо дотримання строгої дисципліни та всіх іiі норм. Адже полонені не могли ніяк позбутися впливу на них правил і традицій таборових товариств, часто нехтуючи організацією військової структури. Однак незважаючи на це утворені з полонених військові частини під керівництвом старшин-українців стали важливим чинником загального процесу у формуванні українських збройних сил.

Опинившись на Волині під час гетьманського перевороту, у лавах Сірожупанників відчувалося певне настороження й очікування змін, які невдовзі прийшли. Новим командиром дивізії призначено генерал-хорунжого Сокиру-Яхонтова, який почав проводити розкладову роботу, почалися масові втечі козаків, серед них багато національно свідомого вояцтва, що завдало великого удару військовій частині. Як виявилося згодом, СокираЯхонтов був зв' язаний з більшовиками. 28 серпня 1918 р. дивізію було передано австрійським командуванням Українській державі, яка наступного дня присягнула на вірність ій та Гетьману. 
Незабаром Сіра дивізія, за розпорядженням гетьманського уряду, була передислокована на Чернігівщину у Конотопський район замість Києва чи Одеси, як того сподівалися Сірожупанники. Розквартирувавшись по чернігівських селах, дивізійники пересвідчились у надмірному надужитті місцевої влади, офіційній перешкоді національно-культурній праці, арештах українських діячів та жорстокій діяльності каральних органів. До цього дуже спричинилися російський саботаж і більшовицька агітація.

У жовтні 1918 р. наказано звільнити в запас козаків старшого віку (близько 1200 осіб, в т.ч. 250 старшин), а далі - молодших річників, так що під час повстання проти Гетьмана в полках залишилося по 80-100 козаків і по 30-40 старшин (Бутович, 1966: 31). Перейшовши на бік Директорії, дивізія (командири отаман Палій, пізніше підполковник Абаза) тимчасово збільшилася до 6 тисяч вояків за рахунок мобілізації. Однак у боях 3 більшовиками на Чернігівщині проти т.зв. Першої радянської української дивізії Сірожупанники не хотіли воювати і були демобілізовані. 3 них більшовики сформували «Красноармейскую Серую дивизию», яка згодом була розпорошена по різних частинах Червоної Армії (Мандзенко, 1996: 16).

Після чергової демобілізації та відходу з Чернігівщини на Правобережжя Сірожупанники були перейменовані в Сіру дивізію (2,5 тис козаків i старшин) під командуванням генерала А. Пузицького. Тут вони з середини січня 1919 р. воювали проти більшовиків у районі Коростеня, Овруча, Житомира і Бердичева, де зазнали важких втрат. У травні 1919 р. на протипольському фронті більшість Сірих потрапили в полон, а рештки пробилися до Ланівців на Південну Волинь, утворивши 4-ту Сіру стрілецьку дивізію (700 багнетів, командир - П. Ганжа) у складі Волинської групи Армії УНР, а іiі залишки (4 Сіра бригада у складі 2-ї Волинської дивізії) воювали до листопада 1920 р., тобто до їх інтернування разом 3 іншими армійськими частинами УНР у таборах Польщі (Срібняк, 1997: 45).

Українські військові відділи формувалися 3 полонених українців і у таборах Німеччини. Мирова делегація в Берестю звернулася від імені українського народу до всіх полонених офіцерів і солдатів у німецьких таборах «Поставити себе до розпорядження Української Центральної Ради, щоб тепер після підписання почесного і демократичного миру визволити свій 
Рідний Край - Україну від анархії, яку ширять большевицькі банди. Для цієї цілі творяться 3 полонених українців здисципліновані відділи» (До украӥнських офіиерів і солдатів, 1918: 1).

Крім того, українська мирова делегація за підписом М. Любинського від імені Української Народної Республіки та іiі уряду видала наказ всім полоненим українцям ставати в ряди зорганізованої української армії для оборони своєї держави від нападу грабуючих Рідний Край, чужинців. Зрадником вважався той, хто вагався або відмовлявся обороняти свою рідну землю i не допускався на Батьківщину. Делегація наголошувала на негайному виконанні полоненими цього наказу (Украӥнське правительство до полонених україниів, 1918: 1).

На допомогу Вітчизні поспішили полонені українці трьох таборів у Німеччині, в яких на той час перебувало до 100 тисяч осіб. Вони за покликом Зальцведельської Української громади 3 одушевленням ухвалювали «душу й тіло за Вітчизну-Україну покласти». Громада полонених табору Ганновер-Мюндену, відгукнувшись на заклик мирової делегації у Бересті, постановила одноголосно «йти на оборону волі й добробуту рідної землі».

Виконуючи наказ українського уряду, генерал Віктор Зелінський 13 лютого 1918 р. приступив до формування дивізії Синьожупанників (назва від кольору уніформи). За його наказом сформовано штаб дивізії: начальник - полковник Янів, члени Сиротенко, Крушинський, Т. Омельченко, всі видатні старшини та свідомі українці. 3 кожного українського табору було відібрано по 2 тисячі, загалом 6 тисяч свідомих козаків (Зелінський, 1938: 22). Наприклад, 17 лютого 1918 р. з Раштатського табору виїхав на Україну полк ім. І. Богуна у складі 800 чоловік, а 3 березня - полк ім. І. Виговського кількістю 1200 козаків. «Від'їзд обох січових відділів, - зазначав О. Терлецький, відбувся урочисто.., але в хвилі їх виїзду з табору не можна було мати надто рожевих надій» (Терлецький, 1918: 360-361).

Синя дивізія складалася 3 4-х піхотних полків (командири Пухтаєвич, М. Чехівський, Малохатка і Блоха), в кожному по 1200 вояків і старшин, 3 батареї по 4 гармати і 36 кулеметів (До справи помочі Украӥнській Народній Республіиі, 1918: 128-130).

Після остаточного сформування у Ковелі (Волинь) дивізія у середині березня 1918 р. прибула до Києва. Командування частини дружелюбно зустріла Центральна Рада, зокрема ії голова 
М. Грушевський. Проте з боку окремих членів уряду, зосібно міністра військових справ О. Жуковського, відчувалася якась невдоволеність. Хоч, як згадував Зелінський, князь Урусов високо оцінював Синьожупанників, вважав їх сильно вихованою патріотичною організацією. «На це, - зазначав генерал, - я йому відповів, що мені дуже приємно вислухати похвали для моїх козаків. Одначе заслуга не в мені, а у праці Союзу визволення України в таборах полонених у Німеччині» (Зелінський, 1938: 50).

24 березня 1918 р. у Києві на Софіївському майдані відбувся парад дивізії, який приймав військовий міністр УНР О. Жуковський у присутності представників української влади і німецькоавстрійського командування. Ввечері у Національному театрі на честь вояків Першої Української дивізії був організований перегляд вистави «Запорожець за Дунаєм» за участю трупи М. Садовського. Перед початком вистави у присутності голови та членів Центральної Ради прозвучали гімн «Ще не вмерла Україна» та «Заповіт». Після того перед вояками виступив М. Грушевський. «Ми знаємо, - сказав він, - що ви стомилися по роках тяжкої війни, вас серце тягне до рідних огнищ. Але ще кілька місяців ви повинні послужити Україні, заки військо, яке тепер твориться, не замінить вас. Ми сподіваємося, що вірно послужите, поки вас не відпустять, що серед вас не буде ворогів України та не знайдуться люди, котрі в хвилину небезпеки проголосять себе нейтральними». Далі він заявив, що німці (на той час австронімецькі війська вже перебували в Україні) не задумують нічого недоброго і не бажають скористатися трудними обставинами, а прагнуть, щоб Україна вийшла 3 боротьби 3 большевиками сильною та незалежною (LAC. R-2297-0-3-E, Vol. 15, File 27).

Однак внаслідок політичної невизначеності зі сторони військового відомства, зокрема його міністра О. Жуковського, стосовно чіткого плану військового будівництва, непевності тогочасної політичної ситуації, а також різноманітних інтриг німецького уряду та його військового представництва в Україні дивізію Синьожупанників було розформовано.

25 квітня 1918 р. видано відповідний наказ за підписом О. Жуковського та начальника канцелярії військового міністерства М. Ковалевського. У ньому, зокрема, зазначалося, що «всі полки можуть бути розпущені 3 пунктів їх теперішнього розташування без їх канцелярій у Києві» (Зелінський, 1938: 70). Напередодні 
гетьманського перевороту - 29 квітня 1918 р. - німці роззброїли синьожупанників. Також була розпущена Друга Синя дивізія, сформована у с. Голобах на Ковельщині, перед іiі виїздом до Києва.

Варто наголосити на ролі німців у справі синьожупанників. У наказі військового міністра УНР О. Жуковського йшлося про розформування двох дивізій за згодою німецького командування. Спостерігалася якась розбіжність у діях німців, які спочатку погодилися на організацію українських військових частин на своїй території, а потім їх роззброювали. Очевидно, справа полягала ще в тому, що німці, 3 одного боку, відчували,. а напевно і знали про упереджене та недовірливе ставлення до себе з боку деякої частини членів Центральної Ради й уряду, які не виконували умови і взяті зобов'язання Берестейського мирного договору, знали про таємні переговори окремих лідерів українських соціалістів 3 більшовицькими представниками у Києві, спрямовані проти Центральної Ради та на розрив німецькоукраїнських домовленостей. Тому німці, 3 другого боку, i підтримали військове міністерство стосовно розформування дивізії синьожупанників, воліючи мати справу 3 Центральною Радою й урядом без війська як $з$ добре дисциплінованим свідомим самим військом. До речі, П. Скоропадський також боявся сильної української армії, ведучи переговори з німецьким командуванням в Україні з приводу перебрання влади - перевороту. Адже проти цього акту могли виступити також дивізії Синіх, через що їх роззброєно напередодні перевороту, що стало, до певної міри, несподівано й для українського уряду (Зіленський, 1938: 75).

Чимало синьожупанників відіграло позитивну роль у державному житті України, влившись до інших військових формацій. Спроби відновлення дивізії Синьожупанників довели лише до створення 7-го Синього полку, командиром якого був Микола Шаповал, у складі Третьої Залізної Стрілецької дивізії під командуванням генерала Олександра Удовиченка. У листопаді 1920 р. дивізія разом 3 іншими формуваннями армії УНР відступила за Збруч і була інтернована у таборах Польщі (Енциклопедія українознавства, 2000: 2820, 3255-3256).

Про створення українських військових формувань 3 полонених українців у таборах Австро-Угорщини та Німеччини Д. Дорошенко писав: «Так і не вдалося використати збройну 
українську силу, яка організувалася на чужині в полоні, в той час, коли ця сила була найбільш потрібна. Сталося трагічне непорозуміння: влада Центральної Ради боялася «самостійництва» полонених, влада гетьманська - їх «революційності» (Дорошенко, 1954: 39). Окупаційні німецько-австрійські війська, перебуваючи в той час в Україні, відстоювали інтереси своїх держав і боялися, щоб відроджена Українська держава не мала сильної власної армії й тому розпустили українські військові частини, сформовані та зорганізовані за їхньою участю на своїх територіях.

Висновок. Синьожупанники і Сірожупанники після розформування незважаючи на різні перешкоди до кінця виконали свою клятву на вірність Україні. Колишні вояки, пройшовши велику школу національного освідомлення під егідою СВУ у таборах полонених у Центральних державах, тепер проводили значну культурно-просвітню працю серед земляків у рідному краю, а в часи Директорії частина 3 них знову стала в ряди української армії, займали поважні пости в Українській державі. Вони залишилися вірними i непохитними борцями за українську справу та здобули собі почесне місце в історії визвольних змагань українського народу. Нинішній Українській державі для зміцнення свого внутрішнього і зовнішнього становища запорукою повинна власне й стати сильна українська армія.

\section{Використані посилання}

Бутович М. (1966). Формування Сірої дивізії у Володимирі-Волинському. За державність. Торонто. Ч. 11. С. 18-41.

Перші роковини Української Центральної Ради. (1918). Вістник політики, літератури і життя (далі - Вістник політики). Відень. Ч. 13. С. 185.

Гаврилко М. (1979). Початки національно-просвітньої праці серед полонених українців у таборі Фрайштадт. Союз визволення України. 1914-1918. Відень. Нью-Йорк. С. 7-8.

Глевкий А. (1916). До полонених українців. Розсвіт. Раштат. С. 1.

Група полонених офіцерів-українців табору Терезієнштадт. (1917). Вістник Союза визволення України (далі-Вістник). Відень. Ч. 17. С. 269.

Даниленко К. (1979). Видавниче товариство ім. Івана Франка. Союз визволення Украӥни. Нью-Йорк. С. 157-174.

Даниленко К. (1979). Розвій суспільно-національної думки в таборі Фрайштадт. Союз визволення Украӥни. Нью-Йорк. С. 13-31.

До всіх громадян Зальцведельського табору. (1917). Вільне слово. Зальцведель. 3 квітня. С. 1.

До всіх полонених офіцерів-українців у Німеччині. (1917). Вістник. Ч. 53. C. $839-840$. 
Дорошенко В. (1967). Всеукраїнське значення УСС. За волю України. НьюЙорк. 608 с.

Дорошенко В. (1954). Союз визволення України. Свобода. Нью-Йорк. № 154. С. 3.

Дорошенко Д. (1954). Історія України 1917-1923 pp. Т. 1. Доба Центральної Ради. Нью-Йорк. 437 с. С. 1 .

До Союзу визволення України. (1917). Громадська думка. Вецляр. 20 січня.

До справи помочі Українській Народній Республіці. (1918). Вістник політики. Ч. 9. 3 березня. С. 128-130.

Доценко О. (1934). Невідома сторінка з легенди про Українських Січових Стрільців. Історичний калєндар-альманах «Червоної Калини» на 1934 рік. Львів. С. $44-51$.

До українських офіцерів і солдатів! (1918). Вільне слово. Зальцведель. 16 лютий. С. 1.

Дубрівний П. (1979). Товариство «Січ» ім. гетьмана Петра Дорошенка у таборі Фрайштадт. Союз визволення України. Нью-Йорк. С. 73-78.

Енциклопедія українознавства. (2000). Львів. Т.8., Т. 9.

Заклик Бойової Управи УСС до українського народу. (1914). Діло. Львів. 7 серпень. С. 1 .

Зелінський В. (1938). Синьожупанники. Берлін. 76 с.

Золотий вінець України. (1917). Громадська думка. Вецляр. 6 травень. С. 1.

Конференція українських таборових організацій в Німеччині. (1917). Вістник. Ч. 45. С. 712.

Литвин В. (2008). Історія Украӥни. Київ. 814 с.

Мандат президентові Союза визволення України Олександрові СрокописуЙолтуховському. (1917). Вецляр. 3 травня. С. 1.

Мандзенко Й. (1966). Сірожупанники. За держсавність. Торонто. № 11. С. 5-17.

Організація частин українського війська 3 полонених у таборі Фрайштадт і вимарш І-го куреня на Україну. (1918). Вістник політики. Ч. 11. С. 160-161.

Патер I. (2000). Союз визволення Украӥни: проблеми державності $i$ соборності. Львів. 345 с.

Перша українська конференція в Німеччині. (1917). Вільне слово. Зальцведель. 9 травень. С. 1.

Полонені офіцери-українці табору Йозефштадт у Чехах Українській Центральній Раді. (1918). Вістник політики. Ч. 1-2. С. 17-18.

Полонені на Український національний фонд. 1917. Вістник. Ч. 25. С. 399.

Полонені офіцери-українці до Центральної Української Ради. (1917). Вістник. Ч. 34. С. 541.

Протест полонених українців-офіцерів табору Йозефштадт у Чехах проти розстрілу богданівців. (1917). Вістник. Ч. 41. С. 645.

Прохода В. (1979). Вплив «Фрайштадтської республіки» і СВУ на українську чинність у старшинських таборах у Терезіні та Йозефові. Союз визволення України. Нью-Йорк. С. 51-56.

Святочні поздоровлення від Січових Стрільців Союзови визволення України. (1915). Вістник. Ч. 15-16. С. 16.

Сімович В. (1937). Відгук березневої революції 1917 р. в таборах полонених українців. Калєндар «Просвіти» на 1937 рік. Львів. С. 72-75. 
Сімович В. (1939). Союз визволення України. Дніпро. Львів. с. 51-59.

Смаль-Стоцький Р. (1967). Початок віднови Української держави. Календар-альманах Украӥнського Народного Союзу на 1967 рік. Нью-Йорк. C. 88-96.

Солдати-українці українського табору у Фрайштадті в Австрії до Української Центральної Ради. (1918). Вістник політики. Ч. 1-2. С. 18.

Срібняк I. (1996). Діяльність Союзу визволення України серед полонених старшин-українців у таборах Німеччини й Австро-Угорщини (1915-1918рр.). Київ. С. 296.

Срібняк I. (1997). Діяльність Союзу визволення України серед полонених офіцерів російської армії в Австро-Угорщині (1914-1918рр.). Сурмач. Лондон. Ч. 1. С. $40-46$.

Срібняк I. (2019). Процеси національної самоідентифікації полонених офіцерів-українців в Австро-Угорщині на завершальному етапі першої світової війни. Сучасна українська нація: мова, історія, культура. Матеріали міжнародної науково-практичної конферениії з нагоди 15-річчя кафедри украйнознавства Львівського національного медичного університету ім. Данила Галицького. 16 березня 2019. Львів. С. 231-233.

Субтельний О. (1992). Історія України. Київ. 510 с.

Терлецький О. (1918). Історія украйнської громади в Раштаті 1915-1918. Київ; Ляйпціг. 429 с.

Українське земляцтво «Громада полонених офіцерів у Райхенбергу в Чехах». (1918). Вістник політики. Ч. 5-6. С. 79.

Українське правительство до полонених українців. (1918). Вільне слово. Зальцведель. 2 березень. С. 1 .

Центральний державний архів вищих органів влади та управління Украӥни, ф. 4405, оп. 1.

Центральний державний історичний архів України у Львові, ф. 368, оп. 1.

Library and Archives Canada (LAC). R-2297-0-3-E.

\section{References}

Butovych M. (1966). Formation of the Gray Division in Volodymyr-Volynskyi. For statehood. Toronto. Ch. 11. p. 18-41 [in Ukrainian].

The first anniversary of the Ukrainian Central Rada. (1918). Bulletin of Politics, Literature and Life. Vienna. Ch. 13. p. 185.

Danylenko K. (1979). Development of socio-national thought in the Freistadt camp. Union for the Liberation of Ukraine. New York. pp. 13-31. [in Ukrainian].

Danylenko K. (1979). Ivan Franko Publishing Society. Union for the Liberation of Ukraine. New York. pp. 157-174. [in Ukrainian].

To the Union for the Liberation of Ukraine. (1917). Public Opinion. January 20. S. 1 [in Ukrainian].

To the cause of assistance to the Ukrainian People's Republic. (1918). Bulletin of Politics, Literature and Life. Part 9. March 3. pp. 128-130.

F.Ya. (1917). Free speech. January 17. p. 1.

To Ukrainian officers and soldiers! (1918). Free speech.. February 16. p. 1.

To all citizens of the Salzwedel camp. (1917). Free speech. Salzwedel. April 3. S. 1. [in Ukrainian].

To all captured Ukrainian officers in Germany. (1917). Bulletin of the Union for the Liberation of Ukraine. Ch. 53. pp. 839-840 [in Ukrainian]. 
Doroshenko D. (1954). History of Ukraine 1917-1923. Vol. 1. The era of the Central Rada. New York. [in Ukrainian].

Doroshenko V. (1954). Union for the Liberation of Ukraine. Freedom. New York. № 154, p. 3 [in Ukrainian].

Doroshenko V. (1967). All-Ukrainian significance of USS. For the freedom of Ukraine. New York. 608 p. [in Ukrainian].

Dotsenko O. (1934). Unknown page from the legend of the Ukrainian Sich Riflemen. Historical calendar-almanac "Red Viburnum" for 1934. Lviv. pp. 44-51 [in Ukrainian].

Dubrivnyi P. (1979). Sich Society named after Hetman Petro Doroshenko in the Freistadt camp. Union for the Liberation of Ukraine. New York. pp. 73-78 [in Ukrainian].

Encyclopedia of Ukrainian Studies. (2000). Lviv. Vol. 8., Vol. 9 [in Ukrainian].

Havrylko M. (1979). The beginnings of national educational work among Ukrainian prisoners in the Freistadt camp. Union for the Liberation of Ukraine. 19141918. Vienna. New York. pp. 7-8. [in Ukrainian].

Hlevkyi A. (1916). To the captured Ukrainians. Dawn. p. 1. [in Ukrainian].

A group of captured Ukrainian officers from the Tereziienshtadt camp (1917). Bulletin of the Union for the Liberation of Ukraine (hereinafter - the Bulletin). Vienna. Ch. 17. p. 269. [in Ukrainian].

Conference of Ukrainian camp organizations in Germany (1917). Bulletin of the Union for the Liberation of Ukraine. № 45, p. 712 [in Ukrainian].

Lytvyn V. (2008). History of Ukraine. Kyiv. 814 p. [in Ukrainian].

Mandate to the President of the Union for the Liberation of Ukraine Oleksandr Srokopis-Yoltukhovsky. (1917). May, p. 1 [in Ukrainian].

Mandzenko Y. (1966). Gray coats. For statehood. Toronto, Nr 11, p. 5-17 [in Ukrainian].

Organization of units of the Ukrainian army from prisoners in the Freistadt camp and march of the First Tent to Ukraine (1918). Bulletin of Politics, Literature and Life.. Ch. 11, pp. 160-161 [in Ukrainian].

Pater I. (2000). ). Union for the Liberation of Ukraine: Problems of Statehood and Unity. Lviv. 345 p. [in Ukrainian].

The first Ukrainian conference in Germany. (1917). Free speech. 9 May, p. 1 [in Ukrainian].

Prisoners to the Ukrainian National Fund (1917). Bulletin of the Union for the Liberation of Ukraine. $\mathrm{Nr} 25$, p. 399 [in Ukrainian].

Captive Ukrainian officers to the Central Ukrainian Rada (1917). Bulletin of Politics, Literature and Life. Ch. 25. p. 399 [in Ukrainian].

Captured Ukrainian officers of the Yozefshtadt camp in the Czech Republic to Ukrainian Central Rada. (1918). Bulletin of Politics, Literature and Life. Nr 1-2, pp. 17-18 [in Ukrainian].

Prokhoda V. (1979). Influence of the Freistadt Republic and The Union for the Liberation of Ukraine on Ukrainian activity in the Terezin and Josef concentration camps. Union for the Liberation of Ukraine. New York. pp. 51-56 [in Ukrainian].

Yozefshtadt camp captured Ukrainian officers protest in the Czech Republic against the execution of Bohdanivtsi (1917). Vistnyk Soiuza vyzvolennia Ukrainy. $\mathrm{Nr}$ 41, p. 645 [in Ukrainian]. 
Simovych V. (1937). ). Echo of the March Revolution of 1917 in the camps of Ukrainian prisoners. Enlightenment calendar for 1937. Lviv. pp. 72-75. [in Ukrainian].

Simovych V. (1939). Union for the Liberation of Ukraine. Dnipro. Lviv, pp.5159 [in Ukrainian].

Smal-Stotskyi R. (1967). The beginning of the restoration of the Ukrainian state. Almanac calendar of the Ukrainian People's Union for 1967. New York. pp. 88-96 [in Ukrainian].

Ukrainian soldiers of the Ukrainian camp in Freistadt, Austria to the Ukrainian Central Rada. Bulletin of Politics, Literature and Life. (1918). Nr 1-2, p. 18 [in Ukrainian].

Sribniak I. (1996). Activities of the Union for the Liberation of Ukraine among Ukrainian prisoners of war in the camps of Germany and Austria-Hungary (19151918). Kyiv. 296 p. [in Ukrainian].

Sribniak I. (1997). Activities of the Union for the Liberation of Ukraine among captured officers of the Russian army in Austria-Hungary (1914-1918). Trumpeter, $\mathrm{Nr}$ 1, pp. 40-46 [in Ukrainian].

Sribniak I. (2019). Processes of national self-identification of captured Ukrainian officers in Austria-Hungary at the final stage of the First World War. Modern Ukrainian nation: language, history, culture. Proceedings of the international scientific-practical conference on the occasion of the 15th anniversary of the Department of Ukrainian Studies, Danylo Halytsky Lviv National Medical University. March 16, 2019. pp. 231-233 [in Ukrainian].

Subtelnyi O. (1992). History of Ukraine. Kyiv. 510 p. [in Ukrainian].

Terletskyi O. (1918). History of the Ukrainian community in Rastatt (19151918). Kyiv; Leipzig. 429 p. [in Ukrainian].

Festive congratulations from the Sich Riflemen of the Union for the Liberation of Ukraine (1915). Bulletin of the Union for the Liberation of Ukraine. Nr 15-16, p. 16 [in Ukrainian].

Ukrainian government to captured Ukrainians. (1918). Free speech. (1918), 2 March, p. 1 [in Ukrainian].

Ukrainian Fellowship "Community of Captive Officers in Reichenberg in the Czech Republic" (1918). Bulletin of Politics, Literature and Life. Nr 5-6, p. 79 [in Ukrainian].

The appeal of the USS Combat Command to the Ukrainian people. (1914). Businnes. Lviv. August 7. p. 1 [in Ukrainian].

Golden crown of Ukraine. (1917). Public Opinion. (1917), 6 May, p. 1 [in Ukrainian].

Central State Archive of the highest authorities and administration of Ukraine, f. 4405 , op. 1 .

Central State Historical Archive of Ukraine in Lviv, f. 368, op. 1. 


\section{Pater I.}

\section{THE UNION FOR THE LIBERATION OF UKRAINE: MILITARY- POLITICAL POINT (1914-1918)}

The beginning of World War I led to the establishment of the Union for the Liberation of Ukraine by the Naddnipryanshchyna political emigrants. Its central postulate was the defeat of Russia in the war and overthrowing of tsarism, resulting in "free Ukraine will rise on the ruins of the Russian Empire." The fighting on the Russian-Austro-Hungarian-German front caused an increase of Ukrainian soldiers in the Russian army's POW camps in Austria-Hungary and Germany.

Attention is drawn to the Union's activities in the Central Powers' governmental circles. These measures made it possible to separate hundreds of thousands of Ukrainian prisoners of war into separate camps, isolate them from Russian influence, and spread the idea of liberation of the Ukrainian people. The author focuses on the Union leadership's actions to convince influential German and Austro-Hungarian circles of the need to implement a set of political measures aimed at strengthening Ukrainian soldiers' national identity. The development of a broad national-patriotic and cultural-educational work of the Union among the Ukrainian prisoners, separately soldiers and officers, has been highlighted. The results of the Union's hard work are revealed - organization of Ukrainian communities in camps, the involvement of numerous prisoners into Ukrainianness. For establishing national awareness work in the camps, Educational Departments were established. They organized literacy schools, various courses to study the most necessary and relevant subjects, found libraries, reading rooms, choirs, orchestras, built churches, opened tea houses, cooperative shops, sports and military societies, and printing houses, held topical evenings and meetings.

A significant impact on cultural and educational activities among Ukrainian prisoners of war made involvement to the work representatives of captive intellectuals and teachers from Halychyna and Bukovyna. The camp press's role is emphasized, particularly in the mobilizing of training military personnel for the liberation struggle. After the formation of the Central Council and the proclamation of independence of Ukraine, the Union prepared them morally and psychologically for defending the Motherland, successfully formed "Sirozhupannyky" and "Syniozhupannyky" divisions - one of the essential elements of the creation of the Ukrainian national army during the Ukrainian War of Independence 1917-1920.

Keywords: Union for the Liberation of Ukraine, prisoner of war camps, national awareness work, army. 